\title{
Centriole Replication and Nuclear Division in Saprolegnia
}

\author{
By I. B. HEATH* AND A. D. GREENWOOD \\ Department of Botany and Plant Technology, \\ Imperial College, London, S.W.7
}

(Accepted for publication 17 April 1970)

\begin{abstract}
SUMMARY
Paired centrioles in the hyphae and young sporangia of Saprolegnia ferax and Dictyuchus sterile were aligned end to end at $180^{\circ}$ to each other. At the end of interphase new centrioles were replicated on the proximal end of each parent centriole. Each pair of centrioles was associated with a characteristic region of the nuclear envelope, termed the pocket. As the centriole pairs moved apart the mitotic spindle developed between these pockets. Kinetochores, initially found at the equator of the spindle, became polarized as the nucleus elongated. A characteristic association between the nuclear envelope and astral microtubules is described and its role in nuclear division discussed. Mitochondria frequently lay along tracts of microtubules. The processes of centriole replication, spindle formation and nuclear division are discussed in relation to reports of the ultrastructure of these processes in other organisms.
\end{abstract}

\section{INTRODUCTION}

Vegetative nuclei of Saprolegnia ferax divide by a type of mitosis which involves a small intranuclear spindle accompanied by paired centrioles situated external to pockets on the nuclear envelope at each pole of the spindle (Heath \& Greenwood, I968). The present work was undertaken to provide a more detailed account of nuclear division and centriole replication.

\section{METHODS}

Saprolegnia ferax (Gruithuisen) Thuret was vegetatively subcultured from the strain used by Manton, Clarke \& Greenwood (195I). Dictyuchus sterile Coker was supplied as isolate 34IC from the Aquatic Phycomycete Culture Collection of Reading University. Vegetative colonies were grown and prepared for electron microscopy as described by Heath \& Greenwood (I968). All dimensions quoted are approximations.

\section{RESULTS}

Paired centrioles were observed adjacent to nuclei which showed no signs of mitosis (Pl. 5, fig. Io) suggesting that one pair of centrioles was associated with each nucleus throughout interphase. Each centriole was composed of a cylinder of nine triple tubules; the three tubules of each group have been designated A (innermost), B and C by Gibbons \& Grimstone (I960). The A tubules were longest at $0.2 \mu \mathrm{m}$.; constant differences in the length of the $\mathrm{B}$ and $\mathrm{C}$ tubules gave the proximal end of each centriole a characteristic wedge shape (Pl. 2, fig. 5 ; Pl. 3, fig. 7 ; Pl. 5, fig. IO). The triple tubules were embedded in a small variable amount of electron-opaque material (Pl. I, fig. I, 3).

* Present address: Department of Botany, University of Georgia, Athens, Georgia 3060I, U.S.A. 
The proximal end of each centriole contained a 'cartwheel' (Gibbons \& Grimstone, I960) comprising a central, I $30 \mathrm{~nm}$. long, cylindrical hub connected to the A tubules by nine radial spokes (P1. I, fig. I, 3), each composed of a thin lamella with a thickened proximal end which was level with the ends of the A tubules (Pl. 2, fig. 5; Pl. 5, fig. I0). Each spoke had a dense bar at a radius of $45 \mathrm{~nm}$. (Pl. I, fig. 3; Pl. 5, fig. ro).

In vegetative hyphae, and at an early stage in zoosporogenesis, centrioles always occurred in pairs aligned at $180^{\circ} \pm 20^{\circ}$ with their proximal ends facing ( $\mathrm{Pl}$. 2, fig. 5; Pl. 5, fig. Io) so that the triplet tubules in each centriole were opposed with respect to the corresponding subfibres in the other centriole (cf. Pl. I, fig. I, 3). Adjacent centrioles were rarely more than $20^{\circ}$ out of line and had a constant gap of $20 \mathrm{~nm}$. between their proximal ends (Pl. 2, fig, 5; Pl. 5, fig. 10). We detected no structure connecting mature centriole pairs (Pl. I, fig. 2). Each pair of centrioles lay adjacent to, and about $70 \mathrm{~nm}$. from, a differentiated region of the nuclear envelope termed the pocket. This term will be used to refer specifically to the differentiated membranes and excludes the cavity which they may enclose. A pocket had a diameter of about $0.5 \mu \mathrm{m}$. and was defined by an increased osmiophilia of the membranes which had a less undulating profile and a constant distance between them (Pl. I, fig. I, 2, 3, 4).

At the end of interphase the paired centrioles moved a short distance apart and daughter centrioles developed simultaneously on the proximal end of each old centriole. The earliest stage of replication detected (Pl. 2, fig. 5) showed young centrioles with a full width cartwheel and A and B, but no C, tubules. The cartwheels of the daughter centrioles were about half their mature length, yet the spokes possessed thickened proximal edges. At this stage the hubs of parent and daughter cartwheels were joined ( $\mathrm{Pl}$. 2, fig. 5). The hub and triple tubules then elongated. The $\mathrm{B}$ and $\mathrm{C}$ tubules developed more slowly than the A tubules, so that the distal ends of young centrioles were also chamfered (Pl. 3, fig. 7). When the daughter centrioles were mature there were then two pairs of closely adjacent centrioles, each with a nuclear pocket.

Centriole replication was apparently the first step in nuclear division. After maturation the two pairs of centrioles began to move apart, each still associated with its pocket. Microtubules began to develop from the region of the pockets (Pl. I, fig. 4; P1. 3, fig. 8). At all stages of mitosis the polar ends of the tubules terminated in a $30 \mathrm{~nm}$. thick region of amorphous material adjacent to the nuclear pockets (PI. I, fig. I to 4 ; Pl. 3, fig. 8; Pl. 4, fig. 9; Pl. 5, fig. I I). The tubules radiating from the pockets rapidly became orientated into a small spindle (P1. I, fig. 4) and at this stage there appeared to be dense material between the two groups of tubules. This dense material excluded intranuclear ribosome-like granules and some of it appeared to be associated with microtubule terminations which resembled kinetochores (Heath \& Greenwood, I968) (Pl. I, fig. 4). The centriole pairs continued to migrate and the spindle became longer and acquired more tubules. Plate 4 , fig. 9 may represent a metaphase stage in division since there are equatorial kinetochores. The spindle continued to elongate and the nucleus and nucleolus became 'dumbbell'-shaped (see Pl. 2, fig. 2, Heath \& Greenwood, I968). At this stage, kinetochores were found near the pole of what may be described as a telophase nucleus (Pl. 5, fig. I I). After the daughter nuclei had been formed, presumably by breakdown of the narrow isthmus of the telophase nucleus, the spindle tubules broke down, still retaining the close association between their polar ends and the nuclear pocket.

At the time of centriole replication a few, probably less than 20 , astral tubules 
radiated from the region of the centrioles out over the nuclear envelope and into the cytoplasm (Pl. 2, fig. 6). As the centrioles migrated the astral tubules became reorientated so that from each centriole pair tubules radiated along the nuclear envelope towards the opposite pole and also away from the poles into the cytoplasm ( $\mathrm{Pl}$. 4, fig. 9) (cf. Aist, 1969). Some, but not all, of these tubules had one end inserted in the dense material in which the centriole triplets were embedded. Throughout mitosis the centrioles were located at the poles of the spindle. The nucleus, however, usually extended beyond the centrioles and often formed pointed processes whose membranes were characteristically associated with astral tubules (Pl. 4, fig. 9; Pl. 6, fig. I4 to I6) to which they were closely apposed, though separated from them by a fairly constant space of $8 \mathrm{~nm}$. (Pl. 6, fig. I6). This characteristic close association was confined to the nuclear envelope. However, mitochondria frequently lay along microtubules (P1. 5, fig. I2, I3). It is not possible to say if these tubules were extensions of astral tubules or if they were cytoplasmic microtubules.

Contrary to the findings of Trow (1895) and Smith (1923) various phases of mitosis were observed in sporangia delimited by a complete basal cross wall.

The above observations were all made on Saprolegnia ferax. Plate 3, fig. 8 suggests that the centrioles of Dictyuchus sterile have a similar structure and behave in the same manner as those of S. ferax.

\section{DISCUSSION}

\section{Structure and replication of centrioles}

The centrioles of Saprolegnia ferax and Dictyuchus sterile were structurally essentially similar to those described in most fungi, e.g. Allomyces (Renaud \& Swift, 1964), Catenaria (Ichida \& Fuller, 1968) and Blastocladiella (Lessie \& Lovett, I968), and differed significantly only in length from those of animal cells, e.g. hamster (Stubblefield \& Brinkley, 1967), although the spiral structure described by these authors was not detected. However, the $180^{\circ}$ orientation has only been reported in the Oomycetes Albugo (Berlin \& Bowen, 1964) and Achlya (Tontz, 1969) and recently in Anthoceros and Marchantia (Moser \& Kreitner, 1970). Contrary to the suggestion of Berlin \& Bowen (1964) the $180^{\circ}$ configuration is the normal interphase condition, not a stage in replication.

In Viviparis (Gall, I96I), Zamia, Marsilea (Mitzukami \& Gall, I966), Chlamydomonas (Johnson \& Porter, 1968), Tetrahymena (Allen, I969), hamster (Stubblefield \& Brinkley, 1967) and chick (Kalnins \& Porter, I969), young centrioles, or the analogous kinetosomes, possess a short but full width cartwheel upon which the A, B and C tubules are added in sequence. These centrioles then elongate to their mature size. Young kinetosomes of Oedogonium zoospores possess cartwheels which are not detectable in older kinetosomes (L. R. Hoffman, personal communication). This literature, and our own present observations of short cartwheels onto which the triplet tubules are added in the above sequence, has led us to postulate the following system of centriole formation for Saprolegnia ferax. A hub is templated, as a mirror image, on the proximal end of the parent hub. This hub then develops the spokes of the cartwheel, which in turn determine the position of the A tubules. The B and C tubules are then added to the elongating $A$ tubules and the entire centriole elongates to its mature length, the B and $\mathrm{C}$ tubules elongating more slowly than the A tubules. Such a hypothesis allows one to predict that in organisms where young centrioles develop at right 
angles to the parents the parent hub would produce daughter hubs which then migrate. Alternatively, hubs may develop de novo, as must occur in the Myxomycetes which produce centrioles in the absence of mature centrioles. Short hubs with no attached cartwheels have not been described in the literature, but these would be difficult to detect. The system postulated here is essentially similar to that proposed by Randle (1969) and would appear to be applicable to most organisms. There are, however, reports of the development of kinetosomes in which cartwheels are not thought to play a part (Dippell, 1968; Sorokin, 1968), although these authors do describe the formation of a ring of nine A tubules to which the B and C tubules are later added, and Dippell (I968) does show a cartwheel at an early stage in development. As noted by Johnson \& Porter (I968), young, short centrioles are difficult to detect; short cartwheels may be even more elusive.

The replication of Saprolegnia ferax centrioles at late interphase or early prophase agrees with the timing reported for HeLa cells (Robbins \& Gonatas, 1964; Robbins, Jentzsch \& Micali, I968), hamster (Stubblefield \& Brinkley, 1967) and Chlamydomonas (Johnson \& Porter, I968). Gall (I96I) found that Viviparis produces procentrioles at early prophase. As mitosis proceeded these became elongated. Thus the numerous light microscope reports of centriole replication at metaphase (listed in Pollister \& Pollister, 1943) were probably detecting elongation rather than the beginning of replication. However, using chemical blocking treatments, Mazia, Harris \& Bibring (I960) showed that the earliest stage in the replication of the units which determine the poles of nuclear division in urchin eggs was completed in the preceding telophase. These experiments led Mazia (196I) to conclude that the replication of these units was complete well before prophase and that the establishment of the actual poles depended on the migration of the units. This work may indicate a different time for centriole replication relative to $S$. ferax, although blocking experiments may detect an earlier stage in replication than that shown by electron microscopy. Furthermore, in view of the mitoses which lack polar centrioles, it has yet to be established that the centrioles do establish the poles of a mitotic spindle. However, the replication of $S$. ferax centrioles before their migration at opposite poles of the spindle is comparable to the process described in hamster cells (Brinkley, Stubblefield \& Hsu, 1967).

\section{Migration of centrioles}

Brinkley et al. (1967) showed that the poleward migration of centrioles in hamster cells involves microtubules. Since migration in Saprolegnia ferax is accompanied by spindle formation and reorganization of the astral tubules, it is not possible to assign the migratory force to either set of tubules. Depolymerization of the astral tubules at their centriolar ends, and their repolymerization behind the migrating centriole, could occur in such a way as to move the centrioles. If such were the case, the spindle could be aligned by its production between the pockets which always remain associated with the centrioles. However, Robinow \& Marak (1966) and Robinow (personal communication) have shown that spindles comparable to those described here in $S$. ferax develop between differentiated areas of nuclear envelope which are not associated with centrioles in Saccharomyces, Conidiobolus and Morchella. It is probable that the migration of the centriole pairs in $S$. ferax is due to their association with the pockets which are being separated by the developing spindle. Undoubtedly, as the pockets move apart some of the membrane needed to enclose the two daughter 
nuclei is developed between them, but there is no precedent which suggests that its development plays a causal role in their migration.

\section{Formation of microtubules}

The mitotic spindle develops as the centrioles migrate but, as remarked by De Harven (I968), 'the origin of microtubules also remains mysterious'. Microtubules frequently appear to be synthesized from amorphous, osmiophilic material which is often adjacent to centrioles or kinetosomes. For example, Bessis, Breton-Gorius \& Thiéry (1958), Jokelainen (1967) and De Harven (1968) show cytoplasmic microtubules radiating from dense pericentriolar satellites in mammalian cells, and Gall (I96I) and Kalnins \& Porter (I 969) show a build-up of osmiophilic material when new centrioles (composed largely of microtubules) are being produced in Viviparis and chick cells. Thus it is usually suggested that microtubules are polymerized from this osmiophilic material, and since they radiate from the centrioles it is assumed that the centrioles play a major role in either the synthesis or the organization of the tubules. Indeed, Stubblefield \& Brinkley (1967) have suggested that microtubules develop directly from the centriole tubules.

The production of microtubules must involve two basic steps: the synthesis of the subunits, and their subsequent polymerization into tubules. There is growing evidence for the synthesis of the subunits in either the endoplasmic reticulum or the Golgi bodies (Heath \& Greenwood, 1970). In Saprolegnia ferax the spindle tubules always appear to originate from dense material adjacent to the polar pockets, which are specialized parts of the nuclear envelope, which in turn is a specialized part of the endoplasmic reticulum. Furthermore, the build-up of dense material around these pockets, after tubule assembly has been blocked by colchicine (Heath, 1969), may represent an accumulation of subunits around their site of synthesis. Rosenbaum \& Carlson (I969) have shown that colchicine blocks assembly, but not synthesis, of microtubule subunits. Other situations in which specialized regions of the nuclear envelope are likely to be involved in subunit production are the acentric, intranuclear mitosis of Didymium (Schuster, 1964), Saccharomyces (Robinow \& Marak, 1966), Plasmodium (Terzakis, Spinz \& Ward, 1967) and Blepharisma (Jenkins, 1967), where the spindle tubules terminate near a differentiated region of the nuclear envelope, or 'plaque' (Robinow \& Marak, I966). Manton (1964) and Burgess \& Northcote (I968) have shown a close association between microtubules and apparently undifferentiated endoplasmic reticulum. Such an association may be evidence for the synthesis of tubule subunits from morphologically undifferentiated as well as differentiated endoplasmic reticulum.

If enzyme complexes, such as those described by Preston \& Goodman (1968) and Mühlethaler (1967) as responsible for cellulose synthesis, were built into the pocket membranes they could elaborate the subunits from material contained in the perinuclear cavity (endoplasmic reticulum) and pass it, in the form of osmiophilic material, through the inner membrane to the spindle or through the outer membrane to the centrioles and astral tubules. Such a system, if widespread, would remove the need to postulate the passage of subunits through the complete nuclear envelope as discussed by Jenkins ( 1967 ) and could account for the osmiophilia and apparent rigidity of the pocket membranes.

Thus whilst is is suggested that the microtubule subunits in Saprolegnia ferax, and 
probably most other organisms, are synthesized by the activity of a system which may be associated with the endoplasmic reticulum, the frequent presence of centrioles or kinetosomes at the apparent centre of the tubule formation suggests that they too may play a role in the polymerization process. But because many cells which lack centrioles (e.g. those with acentric mitoses listed above) can produce tubules, and because the mitotic cells of Chlamydomonas contain centrioles which do not lie near the developing spindle, some other agent is probably responsible for microtubule polymerization. Why this agent should frequently occur around the centrioles remains unknown (cf. Fuller \& Calhoun, 1968).

\section{Division of chromatin}

The central issue in mitosis is the equipartition of genetic material or chromatin. The organization of chromatin in Saprolegnia has long been the source of considerable controversy. Trow (1895), Smith (1923) and Bakerspigel (1960) have all doubted the existence of chromosomes in Saprolegnia ferax; Hartog (I895) and Höhnk (I935) observed small chromosome-like structures but did not agree on the number, claiming four and seven respectively as the haploid figure. Chromatin in our preparations stained poorly and made a complete description of mitosis difficult. Perhaps a similar difficulty explains why the light microscopists cited above could not agree. The occurrence of kinetochores suggests the formation of chromosomes, but the presence of the latter is unconfirmed. However, our observations appear to be similar to the light microscopical data of Bakerspigel (I960). He noted that the chromatin formed an eccentric cap which became drawn out and arranged itself into two separate portions at the beginning of mitosis, i.e. before the nuclei began to elongate. The eccentric cap may be represented by the dense material shown in Pl. I, fig. 4 and is probably already associated with kinetochores. Chromatin on the equator of the spindle shown in Pl. 4, fig. 9 would still appear as an eccentric mass, whether organized into chromosomes or not, and the nucleus would not show signs of division at the light microscope level (except with special staining with which Robinow (personal communication) has been able to detect spindles in Saprolegnia at the light microscope level). As the spindle elongates, the pole to kinetochore tubules apparently shorten, thus producing two masses of chromatin which probably remain at the poles of the spindle as the nucleus continues to divide. We think this is the probable course of chromatin separation, but until we achieve more positive localization of chromatin in thin sections we cannot be certain.

\section{Separation of nuclei}

There is apparently less chromatinic material in Saprolegnia ferax than in organisms such as Haemanthus (Bajer, 1968). According to Nicklas (1965), the smaller the load to be moved the smaller the mitotic forces involved. This may explain why the spindle in $S$. ferax is smaller than those described in other organisms by Bajer (1968), Krishan \& Buck (I965), Ledbetter \& Porter (1963) and others. However, in S. ferax there is a considerable mass of nucleus and nucleolus which must be separated. The force needed to divide the nucleus may be as great or greater than that needed in other nuclei, since the nuclear material does not disperse but is retained in the persistent nuclear envelope. In other intranuclear mitoses where the spindle is larger than that of $S$. ferax, the poles of the spindle are also the poles of the nucleus, e.g. Catenaria (Ichida \& Fuller, 1968) and Blepharisma (Jenkins, 1967). In S. ferax the nucleus extends beyond the poles of 
the spindle and often forms tapering processes closely associated with astral tubules (cf. the outstanding early observations of Hartog, I895). We suggest that the spindle of $S$. ferax is only capable of generating sufficient force to separate the chromatin and that another system has evolved to divide the nucleus. Holmes \& Choppin (I968) show that virus-infected hamster cells form syncytia in which the nuclei migrate into lines closely associated with bands of microtubules. These tubules are essential to alignment, since colchicine-treated cells lack both microtubules and aligned nuclei. Furthermore, Girbardt (1968) has shown the importance of microtubules in nuclear motility in Polystictus. Porter (1966) reviewed a wide range of structures which move along tracts of microtubules, for example, food in Tokophyra tentacles (Rudzinska, 1965) and melanin granules in melanocyte cells of Fundulus (Bikle, Tilney \& Porter, 1966). Furthermore, Kubai \& Ris (1969) have shown that the chromosomes of Gyrodinium are attached to the nuclear envelope and are separated by movement of the envelope along bundles of microtubules which run through channels external to the nuclear envelope. Thus there is abundant evidence for the principle of movement along tracts of microtubules. We suggest that the consistent association between the nuclear envelope and the astral tubules is evidence for a mechanism whereby the nuclear envelope is able to actively 'crawl' along the apparently rigid tubules, thus pulling the nucleoplasm with it and aiding the elongation and eventual separation of the daughter nuclei. At present it has not been shown that the nuclei move through the hyphae along microtubules in this manner during interphase; but since the nuclei move more slowly than the general cytoplasmic stream, such a system is possible. The frequent observation of mitochondria lying along microtubules suggests that their movement may also be dependent on microtubules but since no close association is found between mitochondrial membranes and the microtubules these may only serve as a guide rather than as a rigid base for movement. A similar association between mitochondria and microtubules has also been noted by Northcote (1969).

The authors wish to acknowledge numerous helpful discussions with Dr J. L. Gay and Dr M. S. Fuller and to thank the S.R.C. for a Studentship to one of us (I.B.H.). This work was submitted in part fulfilment of the requirements of the Ph.D. degree of the University of London.

\section{REFERENCES}

AIST, J. R. (1969). The mitotic apparatus in fungi, Ceratocystis fagacearum and Fusarium oxysporum. Journal of Cell Biology 40, 120-135.

AlleN, R. D. (1969). The morphogenesis of basal bodies and accessory structures of the cortex of the ciliated protozoan Tetrahymena pyriformis. Journal of Cell Biology 4o, 716-733.

BAJER, A. (I968). Chromosome movement and fine structure of the mitotic spindle. Symposium of the Society for Experimental Biology 22, 285-310.

BAKERSPIGEL, A. (I960). Nuclear structure and divisions in the vegetative mycelium of the Saprolegniaceae. American Journal of Botany 47, 94-100.

Berlin, J. E. \& Bowen, C. C. (1964). Centrioles in the fungus Albugo candida. American Journal of Botany 5I, 650-652.

Bessis, M., Breton-Gorius, J. \& Thíkry, J. P. (1958). Centriole, corps de Golgi et aster des leucocytes. Revue d'Hematologie 13, 363-386.

Bikle, D., Tilney, L. G. \& PorteR, K. R. (I966). Microtubules and pigment migration in the Melanophores of Fundulus heteroclitus L. Protoplasma 6I, 322-345.

Brinkley, B. R., Stubblefield, E. \& Hsu, T. C. (1967). The effects of colcemid inhibition and reversal on the fine structure of the mitotic apparatus of Chinese hamster cells in vitro. Journal of Ultrastructure Research 19, I-I8. 
Burgess, J. \& Northcote, D. H. (I968). The relationship between the endoplasmic reticulum and microtubular aggregation and disaggregation. Planta 75, I-I 4 .

De HARVEn, E. (1968). The centriole and the mitotic spindle. In Ultrastructure in Biological Systems. Vol. 3. The Nucleus, pp. 197-224. Edited by A. J. Dalton \& F. Haguenau. New York \& London: Academic Press.

Dippell, R. V. (1968). The development of basal bodies in Paramecium. Proceedings of the National Academy of Sciences of the United States of America 6r, 46I-468.

Fuller, M. S. \& Calhoun, S. A. (1968). Microtubule-kinetosome relationships in the motile cells of the Blastocladiales. Zeitschrift für Zellforschung und Mikroskopische Anatomie 87, 526-533.

Gall, J. G. (I96I). Centriole replication. A study of spermatogenesis in the snail Viviparis. Journal of Biophysical and Biochemical Cytology ro, 163-193.

Gibbons, I. R. \& Grimstone, A. V. (1960). On flagellar structure in certain flagellates. Journal of Biophysical and Biochemical Cytology 7, 697-716.

GirbardT, M. (1968). Ultrastructure and dynamics of the moving nucleus. Symposium of the Society for Experimental Biology 22, 249-259.

HaRToG, M. M. (1895). On the cytology of the vegetative and reproductive organs of the Saprolegniaceae. Transactions of the Royal Irish Academy 30, 649-70I.

HeAtH, I. B. (1969). Structural Aspects of the Growth and Reproduction of Saprolegnia spp. Ph.D. Thesis, University of London.

HeAth, I. B. \& Greenwood, A. D. (1968). Electron microscopic observations of dividing somatic nuclei in Saprolegnia. Journal of General Microbiology 53, 287-289.

HeAth, I. B. \& GREenwood, A. D. (I970). Ultrastructural observations on the kinetosomes and Golgi bodies during the asexual life cycle of Saprolegnia. Zeitschrift für Zellforschung und mikroskopische Anatomie. In press.

HöHNk, W. (1935). Zur Cytologie der Oogon- und Entwicklung bei Saprolegnia ferax (Gruith.) Thuret. Abhandlungen hrsg. vom Naturwissenschaftlichen Verein zu Bremen 29, 308-323.

Holmes, K. V. \& Choppin, P. W. (I968). On the role of microtubules in movement and alignment of nuclei in virus-induced syncytia. Journal of Cell Biology 39, 526-544.

ICHIDA, A. A. \& Fuller, M. S. (1968). Ultrastructure of mitosis in the aquatic fungus Catenaria anguillulae. Mycologia 60, 14I-155.

Jenkins, R. A. (1967). Fine structure of division in ciliate protozoa. I. Micronuclear mitosis in Blepharisma. Journal of Cell Biology 34, 463-48I.

Johnson, U. G. \& PORTER, K. R. (1968). Fine structure of cell division in Chlamydomonas reinhardi. Basal bodies and microtubules. Journal of Cell Biology 38, 403-425.

JoKELAINEN, P. T. (1967). Ultrastructure and spatial organization of the metaphase kinetochore in mitotic rat cells. Journal of Ultrastructure Research 19, 19-44.

Kalnins, V. I. \& Porter, K. R. (I969). Centriole replication during ciliogenesis in the chick tracheal epithelium. Zeitschrift für Zellforschung und Mikroskopische Anatomie 100, 1-30.

KrishaN, A. \& BUCK, R. C. (1965). Structure of the mitotic spindle in L strain fibroblasts. Journal of Cell Biology 24, 433-444.

KubaI, D. F. \& Ris, H. (1969). Division in the dinoflagellate Gyrodinium cohnii (Schiller). A new type of nuclear reproduction. Journal of Cell Biology 40, 508-528.

Ledbetter, M. C. \& Porter, K. R. (1963). A 'microtubule' in plant cell fine structure. Journal of Cell Biology I9, 239-250.

Lessie, P. E. \& LovetT, J. S. (1968). Ultrastructural changes during sporangium formation and zoospore differentiation in Blastocladiella emersonii. American Journal of Botany 55, 220-236.

MANTON, I. (1964). Observations with the electron microscope on the division cycle in the flagellate Prymnesium parvum Carter. Journal of the Royal Microscopical Society 83, 317-325.

Manton, I., Clarke, B. \& Greenwood, A. D. (195I). Observations with the electron microscope on a species of Saprolegnia I. Journal of Experimental Botany 2, 32 I-33I.

MazIA, D. (196I). Mitosis and the physiology of cell division. In The Cell, vol. 3, pp. 77-412. Edited by J. Brachet \& A. E. Mirsky. New York \& London: Academic Press.

MaziA, D., HARris, P. J. \& Bibring, T. (I960). The multiplicity of the mitotic centres and the timecourse of their duplication and separation. Journal of Biophysical and Biochemical Cytology 7, 1-20.

MitzuKami, I. \& Gall, J. (1966). Centriole replication. II. Sperm formation in the fern Marsilea and the cycad Zamia. Journal of Cell Biology 29, 97-I I I. 
Moser, J. W. \& KreItNer, G. L. (I970). Centrosome structure in Anthoceros laevis and Marchantia polymorpha. Journal of Cell Biology 44, 454-458.

MüHLETHALER, K. (1967). Ultrastructure and formation of plant cell walls. Annual Review of Plant Physiology 18, I-24.

Nicklas, R. B. (1965). Chromosome velocity during mitosis as a function of chromosome size and position. Journal of Cell Biology 25, I 19-1 35 .

Northcote, D. H. (1969). Growth and differentiation of plant cells in culture. Symposium of the Society for General Microbiology I9, 333-349.

Pollister, A. W. \& Pollister, P. F. (I943). The relation between centriole and centromere in atypical spermatogenesis of viviparid snails. Annals of the New York Academy of Sciences 45, I-48.

PORTER, K. R. (1966). Cytoplasmic microtubules and their functions. In Ciba Foundation Symposium. Principles of Biomolecular Organization, p. 308. Edited by G. E. W. Wolstenholme \& M. O’Conner. Boston: Little, Brown \& Co.

Preston, R. D. \& Goodman, R. N. (1968). Structural aspects of cellulose microfibril biosynthesis. Journal of the Royal Microscopical Society 88, 513-528.

RANDLE, J. (1969). The flagellar apparatus as a model organelle for the study of growth and morphopoiesis. Proceedings of the Royal Society of London, Series B r73, 31-62.

Renaud, F. L. \& SwiFT, H. (1964). The development of basal bodies and flagella in Allomyces arbusculus. Journal of Cell Biology 23, 339-354.

RoBbins, E. \& GonATAS, N. K. (I964). The ultrastructure of a mammalian cell during the mitotic cycle. Journal of Cell Biology 21, 429-433.

Robiins, E., Jentzsch, G. \& Micali, A. (1968). The centriole cycle in synchronized HeLa cells. Journal of Cell Biology 36, 329-339

RoBinow, C. F. \& MARAK, J. (I966). A fibre apparatus in the nucleus of the yeast cell. Journal of Cell Biology 29, I29-15I.

Rosenbaum, J. L. \& Carlson, K. (1969). Cilia regeneration in Tetrahymena and its inhibition by colchicine. Journal of Cell Biology 40, 415-425.

RudzinsKa, M. A. (I965). The fine structure and function of the tentacle in Tokophyra infusiorum. Journal of Cell Biology 25, 459-477.

SCHUSTER, F. (1964). Electron microscope observations on spore formation in the true slime mould Didymium nigripes. Journal of Protozoology 11, 207-216.

SмIтH, F. E. V. (1923). On direct nuclear divisions in the vegetative mycelium of Saprolegnia. Annals of Botany 37, 63-73.

Sorokin, S. P. (1968). Reconstructions of centriole formation and ciliogenesis in mammalian lungs. Journal of Cell Science 3, 207-230.

Stubblefield, E. \& BRinkley, B. R. (1967). Architecture and function of the mammalian centriole. In Symposium of the International Society for Cell Biology, vol. 6, p. 175. Edited by K. B. Warren. New York: Academic Press.

Terzakis, J. A., SPInZ, H. \& WARD, R. A. (1967). The transformation of the Plasmodium gallinaceum oocyst in Aedes aegypti mosquitoes. Journal of Cell Biology 34, 31 I-326.

TonTZ, J. C. (1969). An ultrastructural study of morphogenesis in Achlya ambisexualis Raper E87 and Achlya imperfecta Coker. Ph.D. Thesis, University of Texas at Austin.

Trow, A. H. (1895). The karyology of Saprolegnia. Annals of Botany 9, 609-652.

\section{EXPLANATION OF PLATES}

Key to symbols: $\mathrm{C}=$ centriole, $\mathrm{Cp}=$ centriole position, $\mathrm{P}=$ pocket, $\mathrm{s}=$ spindle tubule, $\mathrm{N}=$ nucleus, $\mathrm{a}=$ astral tubule, $\mathrm{M}=$ mitochondrion, $\mathrm{Nu}=$ nucleolus, $\mathrm{er}=$ endoplasmic reticulum, $\mathrm{Np}=$ nuclear pore, $\mathrm{V}=$ vacuole.

\section{Plate I}

Fig. I to 3. Saprolegnia ferax. Three members of a series of twelve transverse sections (one missing between fig. I \& 2) through a pair of centrioles (C) at the pole of a metaphase mitotic spindle. The cartwheel and triplet tubules of one centriole are seen in fig. I; no detectable structure is found between the centrioles in fig. 2. Figure 3 shows the proximal end of the second centriole with a well-marked cartwheel and triplet tubules which are arranged at an opposed tangential angle to those in fig. I. Differences in length of the A, B and C tubules, combined with the obliquity of the plane of section in 
fig. 3, reveal a single $A$ tubule (single arrow) and an A-B doublet (double arrow) as well as the triplets typical of the major length of the centriole. The nuclear envelope membranes which constitute the pocket (P) show typical strong osmiophilia (fig. I to 3). Spindle tubules (s) may have a funnel shape (arrowed, fig. I) at their termination in amorphous material adjacent to the pocket. $\times 105,000$.

Fig. 4. S. ferax. An early stage in mitosis in which the two pairs of centrioles (C), each associated with a pocket $(\mathrm{P})$, have begun their migration. A few short spindle tubules (s) have developed between the pockets, and the free end of one of these terminates in a kinetochore-like structure (arrowed) which is associated with osmiophilic material. $\times 8 \mathrm{I}, 600$.

\section{Plate 2}

Fig. 5. S. ferax. The earliest stage in centriole replication yet detected. Parent centrioles $\left(\mathrm{C}_{1}\right.$ and $\left.\mathrm{C}_{2}\right)$ are producing daughter centrioles $\left(C_{3}\right.$ and $\left.C_{4}\right)$ adjacent to their proximal ends. $C_{3}$ and $C_{4}$ have short $A$ and $B$ tubules, lack $C$ tubules but possess short, full width cartwheels. The proximal edges of the spokes of both $\mathrm{C}_{2}$ and $\mathrm{C}_{4}$ are thickened and their hubs are connected (arrowed). Serial sections showed that this section was median and longitudinal to all four centrioles, $\times 186,000$.

Fig. 6. $S$. ferax. The second section in the series below fig. 5 showing the numerous astral tubules (a) radiating from the centriole region $(\mathrm{Cp})$ over the surface of the nucleus $(\mathrm{N}) . \times 43,500$.

Plate 3

Fig. 7. S. ferax. An early stage in centriole migration in which two pairs of nearly mature centrioles, each with triplet tubules and an associated nuclear pocket $(\mathrm{P})$ have moved slightly apart yet spindle tubules have not begun to develop from the pockets. $\times 130,000$.

Fig. 8. Dictyuchus sterile. An early stage in centriole migration and spindle formation showing two pairs of centrioles $\left(C_{1}\right.$ and $C_{3}$ cut obliquely, $C_{2}$ and $C_{4}$ apparently still connected by their hubs) with associated pockets from which short spindle tubules $(\mathrm{s})$ radiate. $\times 100,500$.

\section{Plate 4}

Fig. 9. S. ferax. A later stage in centriole migration than that shown in Pl. I, fig. 4. The presence of a kinetochore-like structure (arrowed) at the equator of the spindle may define this as a metaphase stage of division. Note the close association between the nuclear envelope and the astral tubules (a). $\times 35,200$.

\section{Plate 5}

Fig. Io. S. ferax. Longitudinal section of a pair of interphase centrioles showing the $180^{\circ}$ orientation and the chamfered proximal end of the triplet tubules (arrowed). Note the length of the cartwheel relative to the tubules and the bar of thickening on one of the spokes (open arrow). Nuclear pores $(\mathrm{Np})$ adjacent to the pocket $(\mathrm{P})$ contain osmiophilic material, and the nuclear envelope is extended as a tongue of ribosome-studded endoplasmic reticulum (er). $\times 97,900$.

Fig. I I. S. ferax. Obliquely sectioned centrioles at the pole of a telophase nucleus. The poles were approximately $10 \mu \mathrm{m}$. apart and the mid point of the nucleus was constricted to about $0.25 \mu \mathrm{m}$. in diameter yet it contained microtubules in this narrow isthmus. The structure arrowed has the appearance of a kinetochore, its presence at the pole is consistent with the hypothesized polar position of the chromatin at telophase. $\times 88,500$.

Fig. I2. S. ferax. A mitochondrion lies adjacent to a microtubule (arrowed) but its membrane lacks the close association with the tubule as depicted in Pl. 6, fig. $16 . \times 50,400$.

Fig. 13. S. ferax. A group of mitochondria near the apex of a vegetative hypha. Four microtubules lie close to mitochondria (arrows). Such positioning is sufficiently common to suggest a functional rather than a chance association. $\times 27,000$.

\section{Plate 6}

Fig. 14 and 15. S. ferax. Details of opposite ends of the anaphase-telophase nucleus shown in Fig. 2 of Heath \& Greenwood (I968). The nucleus extends beyond the centrioles (detected in serial sections, marked $\mathrm{Cp}$ ) and the nuclear envelope of these extensions lies close to astral tubules (a). $\times 57,000$ and $\times 72,300$.

Fig. I6. S. ferax. A typical close association between a nuclear envelope and a microtubule (a). Note the small, relatively constant space between the outer membrane of the envelope and the tubule. Arrowheads indicate possible links between microtubule and nuclear envelope. The envelope is drawn out into a narrow projection, the leading edge of which coincides with a bend in the otherwise straight tubule (open arrow). Such a configuration may be evidence for a force between the envelope and the tubule pulling the nucleus along the tubule. $\times 84,600$. 

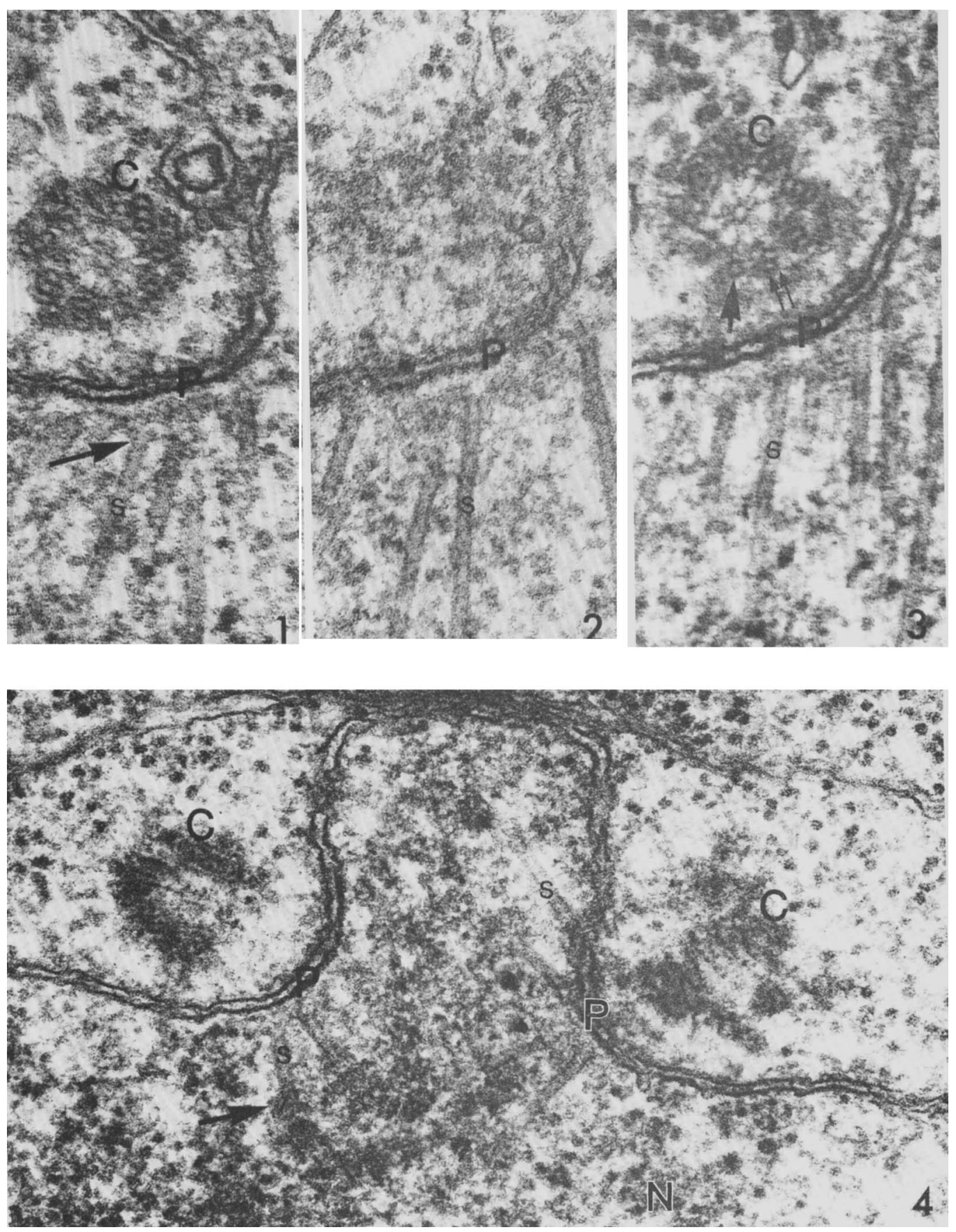

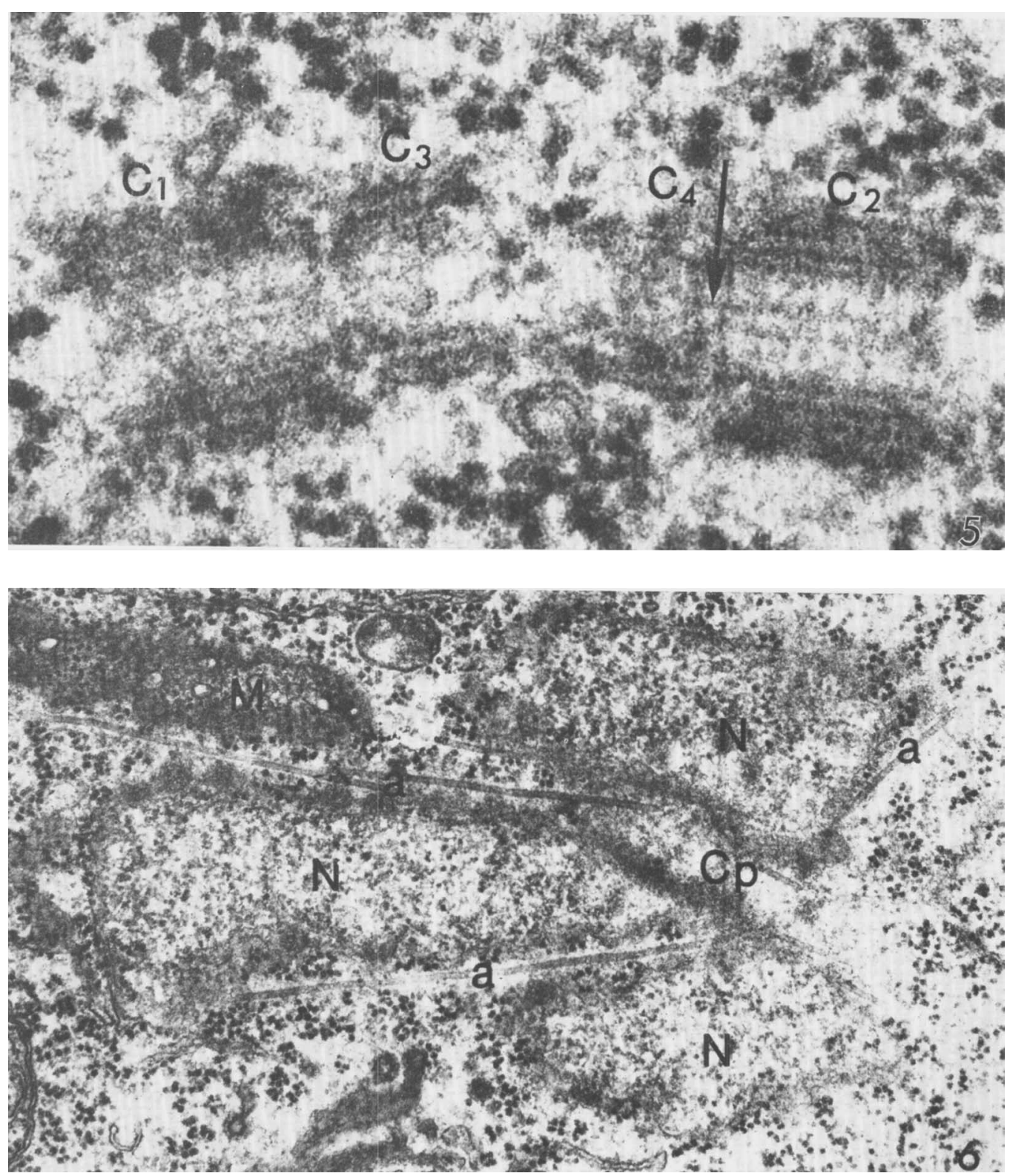

I. B. HEATH AND A. D. GREENWOOD 

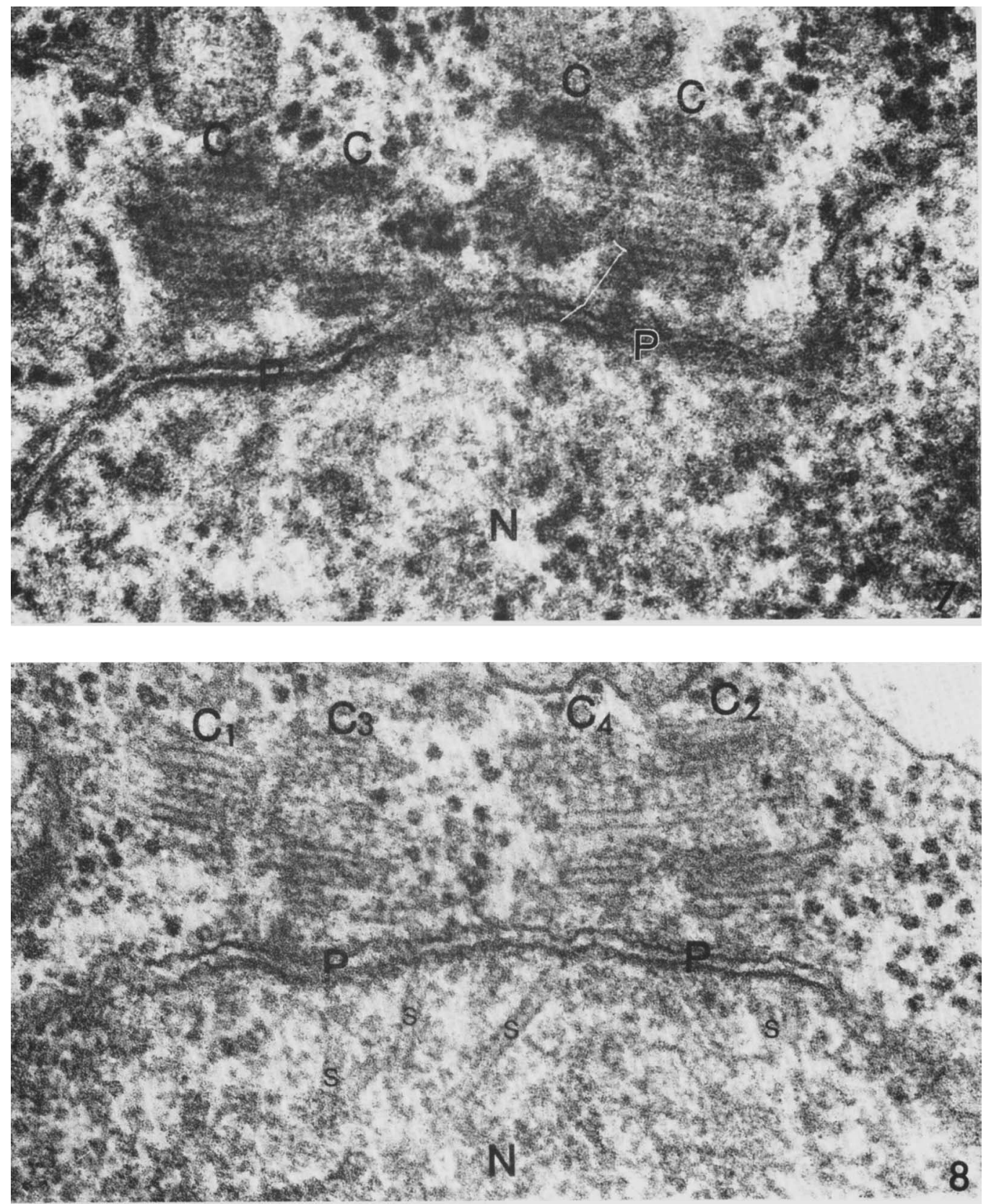

I, B. HEATH AND A. D. GREENWOOD 


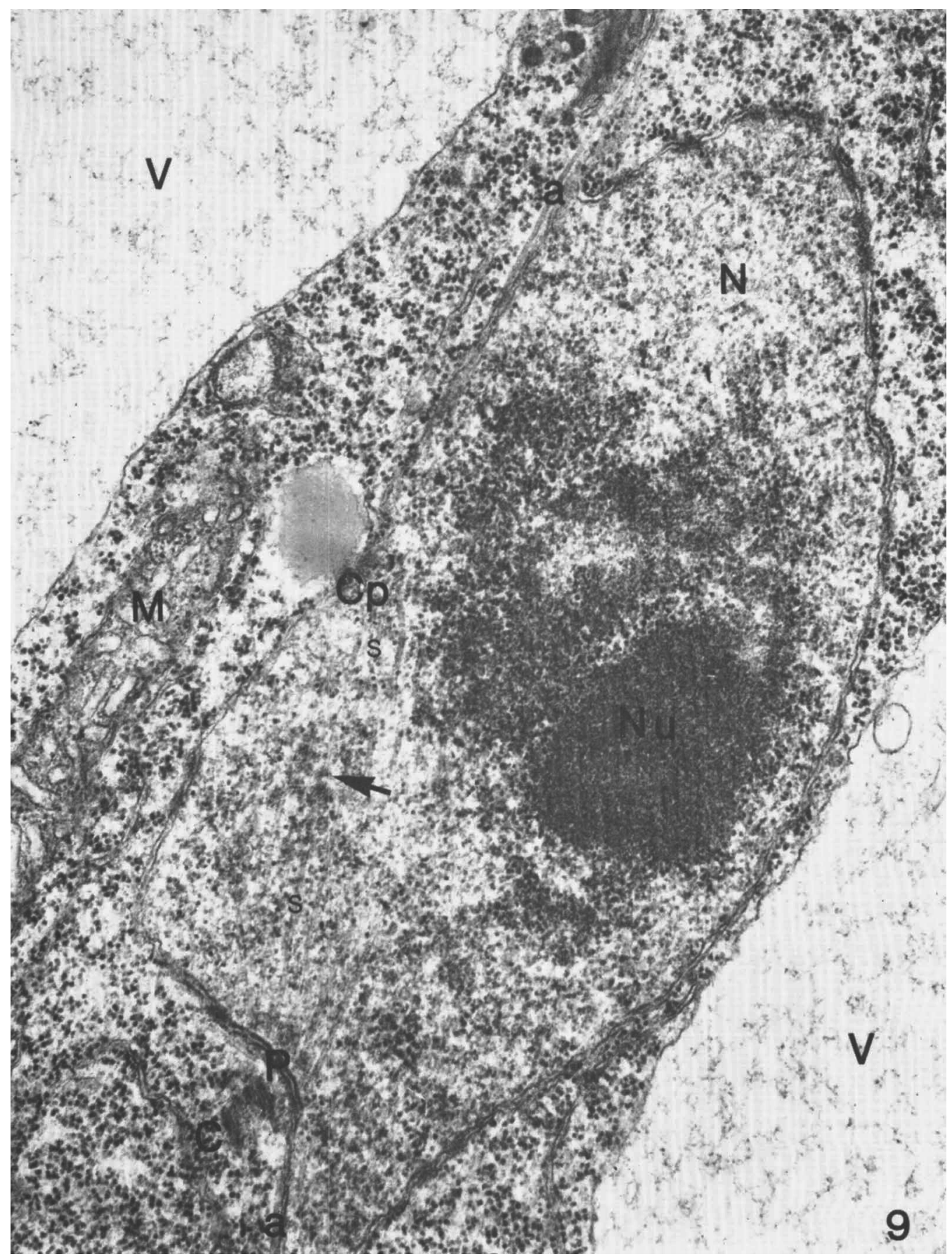

I. B. HEATH AND A. D. GREENWOOD 

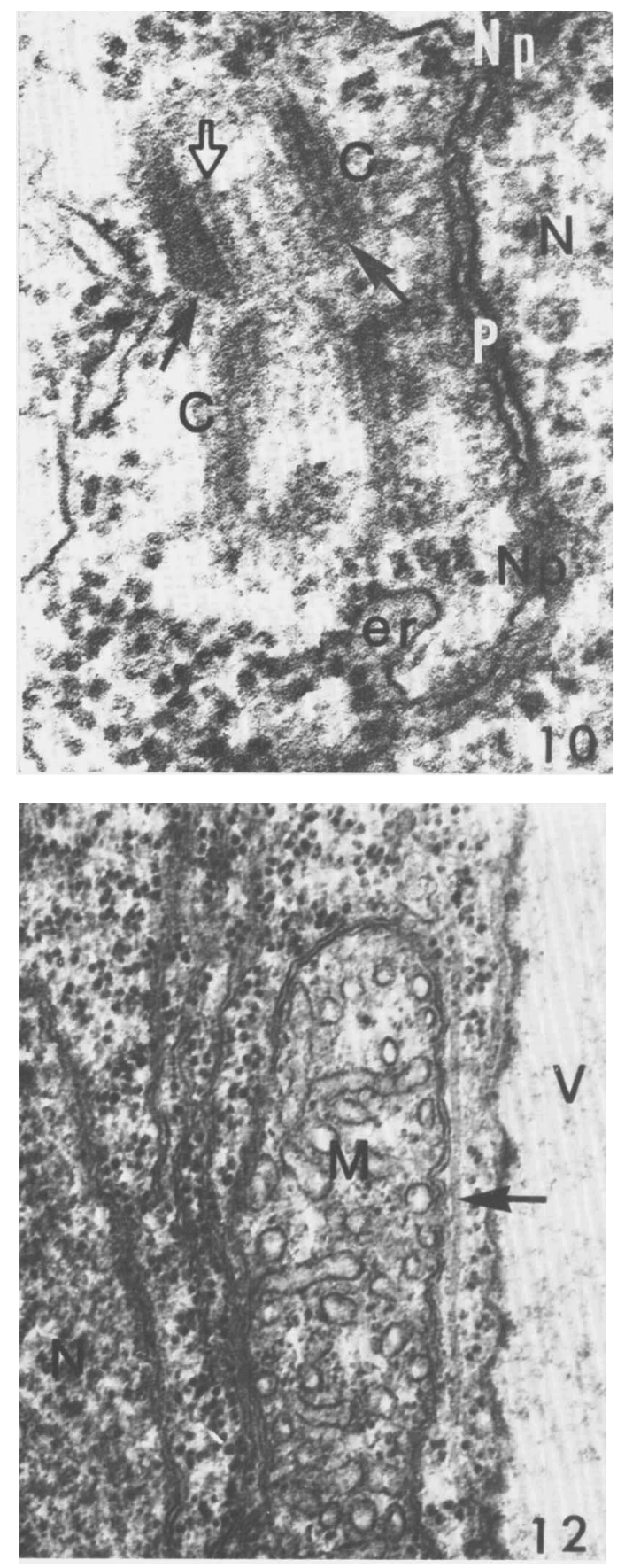
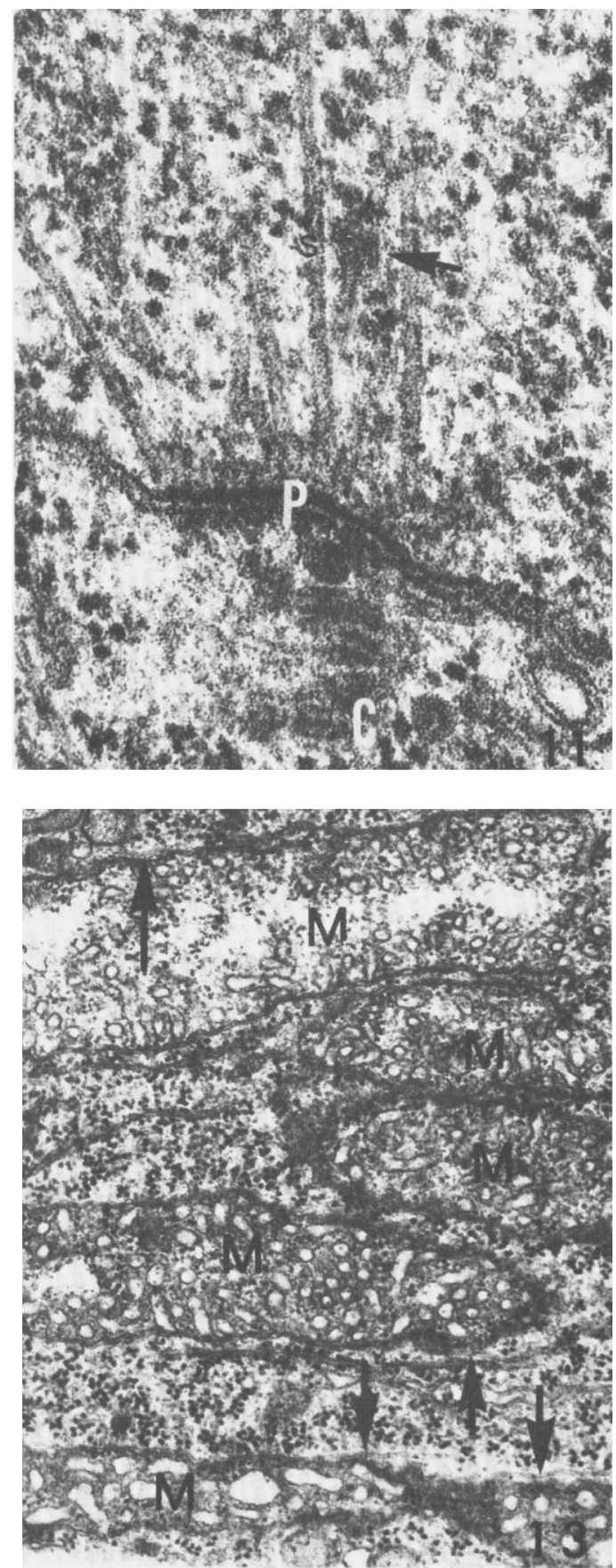

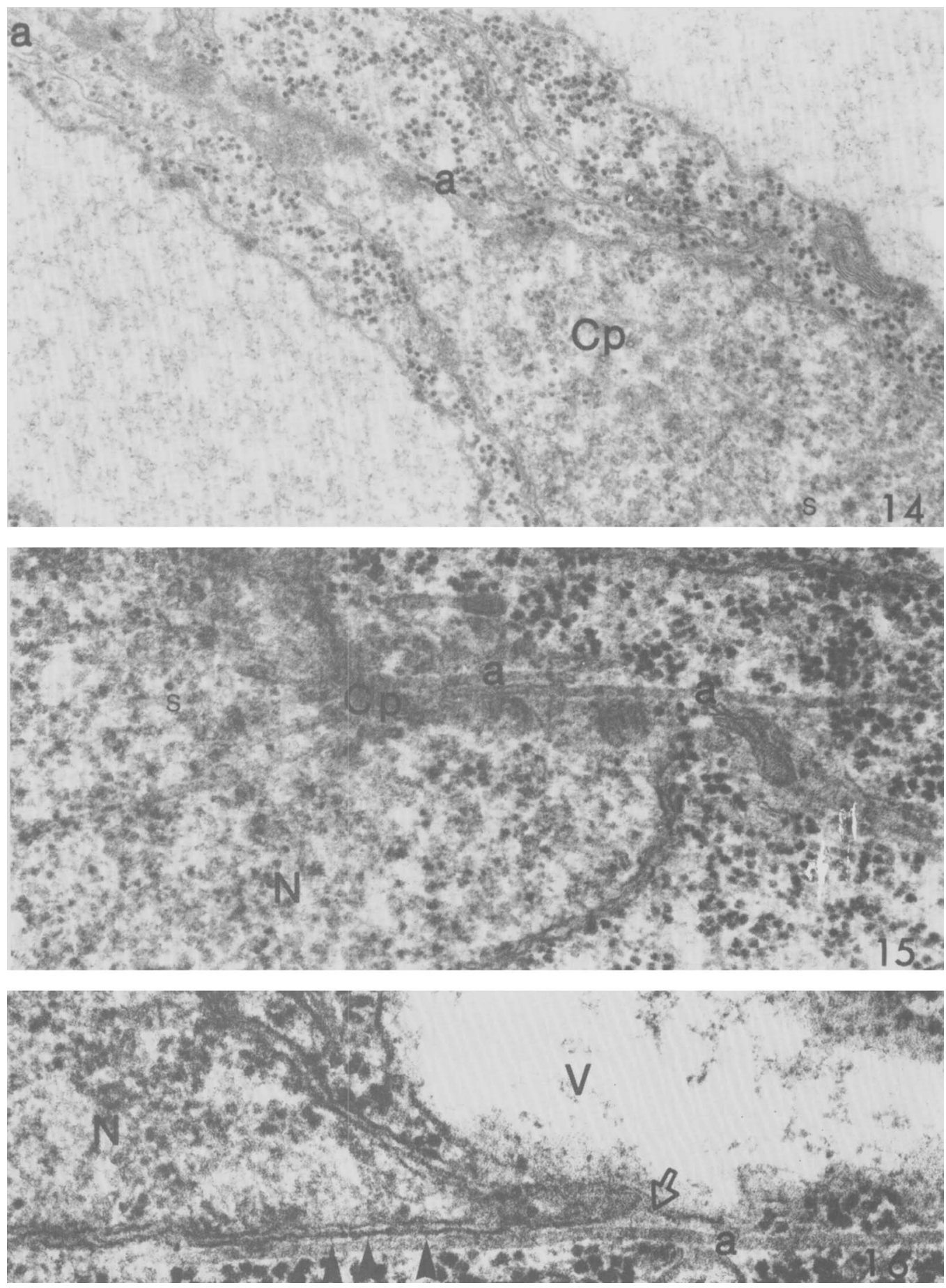

I. B. HEATH AND A. D. GREENWOOD 